\title{
ACtion Research as A TOOL FOR TEACHER AUTONOMY
}

(Pesquisa-ação como instrumento para a autonomia do professor)

\author{
Heliana Mello, Deise P. Dutra \& Miriam Jorge ${ }^{1}$ \\ (Universidade Federal de Minas Gerais)
}

\begin{abstract}
RESUMO: Este artigo enfoca a pertinência da Pesquisa Ação como um instrumento prático no desenvolvimento da autonomia de professores de língua estrangeira. São relatados os resultados obtidos após o desenvolvimento de um ano de pesquisa-ação colaborativa no contexto de um programa de educação continuada. Os passos adotados para o desenvolvimento de tal procedimento são descritos e contextualizados e, para finalizar, são apresentados os resultados obtidos e possiveis direcionamentos a serem adotados para a ampliação de possibilidades no desenvolvimento da autonomia de professores de línguas.
\end{abstract}

PALAVRAS-CHAVE: autonomia; pesquisa-ação; educação continuada; ação colaborativa.

ABSTRACT: This paper focuses on the pertinence of Action Research as a practical tool in the enhancement of language teachers' autonomy. We report on the results achieved after a year of collaborative action research undertaken by teachers enrolled in a Teacher Education Continuing Program and point out the steps taken throughout this initiative. We conclude by reflecting about the insights gained through this experience and additionally point out adaptations and new directions that might be pursued in the search for teachers' autonomy along their careers.

KEY-WORDS: teacher autonomy; action research; continuing education; collaborative action.

\section{Introduction}

The research we present in this article is part of a broader initiative within a continuing education program for language teachers. Our choice to include action research as one of the program activities was due to the

\footnotetext{
1 The authors wish to thank the editors of this volume for their careful reading and valuable suggestions to this paper.
} 
success of other action research projects we have developed with school teachers (Jesus, Mello e Dutra 2007) which led us to see its importance in the path of teacher autonomy. Yet, there were different implications in setting action research in the program rather than with an only teacher in collaboration with a researcher (Dutra e Mello 2004; Dutra 2005). In the action research project reported in Jesus, Mello e Dutra (2007) there was a research team, made up of two senior researchers and one research assistant working with a single public school teacher who was not only willing, but very eager to actually try new ways to improve her teaching and her students' learning. On the other hand, the initiative implemented in the teacher continuing education program was a good will decision made by the program coordinators. Teachers did not know what action research was and only had a general desire to improve their teaching but not necessarily the available time commitment or personal level of engagement to develop an action research project.

The reasons that led us to implement action research projects as a mandatory activity within the continuing education program were the following: the opportunities created for learning and reflecting about Applied Linguistics issues connected to classroom practices, the use of English by the teachers involved in the research and by their students and finally the possibility for problem posing and problem solving. We also believed that the involvement in collaborative action research would help the development of self-esteem, new conceptions of language and of foreign language teaching, strategies for needs analysis, and the ability to reflect in-action and on-action. In order to portray our action research initiative and its connection to teacher autonomy, this article is organized in four sections: theoretical background, methodology, results and conclusion.

\section{Theoretical background}

The notion of teacher autonomy is dependent upon a broader concept centered around the axis of autonomy as a whole. In the Applied Linguistics literature, autonomy has been mentioned and later studied as a central notion related to language learners proficiency development. However, the understanding of learner autonomy inevitably led to the discussion of teacher autonomy since, after all, teachers do play an important role in advancing learners' autonomy strategies and practices. 
The contemporary literature on teachers' autonomy focuses on different attributes associated with the basic notion under discussion. Some view teacher autonomy as an attribute related to freedom in choosing curricular directions. Others focus more on the teachers' capacity to guide students' autonomy. Teacher autonomy may hinge on "ideas of professional freedom and self-directed professional development" (Benson 2001, p.174, citing McGrath 2000); alternatively, teacher autonomy may highlight "critical reflection" (Smyth 1989) and "transformation through dialogue" (Shor \& Freire 1987). According to Little (1995:179), “...(s)uccessful teachers have always been autonomous in the sense of having a strong sense of personal responsibility for their teaching, exercising via continuous reflection and analysis the highest possible degree of affective and cognitive control of the teaching process, and exploiting the freedom that this confers". Therefore, we can infer that in that author's view, autonomy is a more or less instinctive, inherent capability that individuals, not only teachers have. That might well be so, however, a more technical, pedagogically oriented view for the concept must be advanced, at least if educators and teacher trainers want to provide instruments to those individuals who do not already come into the profession with the necessary tools to pursue individual autonomy in the advancement of their performance and personal achievement.

In the search for the development of the necessary conditions to help teachers adapt to the ever increasing demands of society and a diversified body of students, teacher educators ought to investigate whatever tools and methodologies should be employed in this difficult task. Having that in mind, we probably should pursue the notion that teacher autonomy is indeed closely tied to the concept of a critically reflective teacher (Bartlett 1990), which might be achieved through teacher research, exploratory practice, reflective practice and action research. Yet another issue we should deal with is that teacher autonomy is not solely centered on the acquisition of further cognitive and methodological abilities. Many are the continued education programs that fail in their well intended goals due to a lack of understanding that teachers are psycho-social beings and in order to aggregate new knowledge and new practices they need to perform a change in social representations and culture. That can only be achieved if teachers do not feel pressured to do things they do not fully comprehend or accept. In that sense, reflective practice and other closely linked types of research 
are enticing options for teacher educators to foster in their programs since these will help teachers understand their work environment and the social practices there adopted better. Additionally, according to Allwright (2003) in his explanation of Exploratory Practice, teacher educators should be concerned above all with the "quality of life in the language classroom". This will guarantee gains to all involved in the process.

The basic premise in the initiatives mentioned above is that teachers are best placed to develop their own teaching in order to better the learning experiences of their students. Teacher autonomy seems to be an umbrella term for these innovations in teacher education and on-going teacher development. Rather than accepting the received wisdom, the autonomous teacher interprets ideas about teaching and learning for her/himself probably in collaboration with others making the meaning more real for her/himself. Crucially, the autonomous teacher goes beyond this to search for new answers to new problems, which inevitably occur to us as individuals in our own unique teaching/learning situations. In order for teachers to come out of their education as "autonomous professionals" Johnson (2006: 235) argues that we need to provide for "a teaching force of transformative intellectuals who can navigate their professional worlds in ways that enable them to create educationally sound, contextually appropriate, and socially equitable learning opportunities for the students they teach".

There are several possible research initiatives that are adept to help teachers become more autonomous in their practice. Among them, we can highlight teacher research, exploratory practice, reflective practice and action research. (Downhower, Melvin \& Sizemore 1990; Williamson 1992). The common aspect among these possibilities is the active role teachers have in the production of knowledge. Action research in particular makes it possible for teachers to research a theme of their choice, which is focused on their language classroom problems. This very aspect eventually offers teachers the possibility to improve their classroom practice and students' learning. The central features of Action research are systematic inquiry, reflection and focus on practice. Basically, Action research searches for questions and their answers, which emerge from the day to day activities and processes that occur in the language classroom, so that answers are immediately turned into action for the resolution of the detected problems. Action research might be undertaken individually or in groups as a collaborative action. In the Continuing Education Program under focus in 
this paper, action research was carried as a collaborative initiative, which involved, for each research group, four school teachers, a senior member from the project staff, one or more undergraduate students. The rationale for the action research undertaken followed a six step plan: (1) identification of problem/question to be investigated, (2) grouping of information related to the question under focus, (3) development of an action plan, (4) plan implementation, (5) results evaluation, and (6) repetition of the cycle, adjusting the formulation of the basic questions or strategies to solve them, up to the point of finding satisfactory results.

\section{Methodology}

This study reports action research developed over the course of a year with about 50 English public school teachers involved in a continuing education program.

\subsection{Context}

The project in which the public school teachers are involved is called Foreign Language Teacher Continuing Education (Educação Continuada de Professores de Linguas Estrangeiras - EDUCONLE ${ }^{2}$ ) and it is held at Faculdade de Letras of the Universidade Federal de Minas Gerais. This extension, research and teaching project comprises 300 hours in 2 years. The target groups are public school English and Spanish teachers who participate in talks, classes, projects related to four different axes: a) linguistic and methodological issues; b) cognitive aspects of learning; c) action research and d) Brazilian educational themes. The idea that reflection can lead to professional development permeates all four axes.

\subsection{Members of the program and research participants}

The Continuing Education Program is coordinated by UFMG professors from the Language and Education Colleges who additionally teach methodology modules and supervise action research projects.

\footnotetext{
www.letras.ufmg.br/educonle
} 
Graduate students from the Linguistics Program also contribute in the methodology modules, action research and language module orientation, besides doing their own research projects there. Undergraduate students (pre-service teachers) teach the language modules, participate in the methodology modules and develop their own research.

In order to develop the action research project, the public school teachers were grouped according to the problem they wanted to research ${ }^{3}$. They gathered in groups of 4 also with a university professor or a graduate student and one or two pre-service teachers. In the year this report covers there were 13 groups, which met every month to plan and evaluate the action-research project. The members of seven groups were, then, taking the first year at EDUCONLE while the other six were in the second year. Some members of the groups met every week or every other week as they planned activities together and visited each other's classes.

\subsection{Setting the ground to start action research}

Before action research was proposed as an activity at EDUCONLE, a discussion was held about the roles of teacher research so as to raise the participants' awareness concerning its importance. The English teachers read action research literature and its fundamentals were also discussed in class. Then, they brainstormed class problems from which the advisors made a list. From the convergence of the topics, teachers and advisors formed groups. The work done throughout the year involved continuous guidance, including cognitive and affective feedback.

\subsection{Systematization of the research}

As previously mentioned the members of the groups met regularly to discuss what had been done, evaluate the results and plan the following actions. Monthly meetings occurred with the presence of the advisor,

\footnotetext{
3 EDUCONLE participants received initial guidelines for the research providing two options: either the development of action research or the implementation of innovative activities for the classroom. Since most groups chose to develop action research (although as will be seen later in this paper, not all the results complied with the orientations given), this article concentrates on how it was systematized and its results.
} 
however, the public school teachers had other meetings as the group felt it was necessary.

In order to help the members of the group better systematize their research, two seminars and written papers in English were scheduled. All the group members were supposed to present orally using the appropriate visual aids ${ }^{4}$. The seminars occurred in July and December and all the participants received feedback in terms of the presentation itself, the action research being developed and genre adequacy (including format and linguistics aspect). As mentioned above, the groups also had to turn in a written paper discussing the research. Two versions were turned in and the groups also received feedback to improve them. The advisors called teachers' attention to the fact that the seminar and the written paper were very different genres and, therefore, language choices for each genre were discussed.

\subsection{Research phases}

At first the groups discussed together with their advisor a definition of the broad problem. The idea was that if the problem posed was too broad the group should try to narrow it down to an aspect that could be observed and intervened at during the year. At that point this narrowing down many times did not occur.

Second, the members of the group set to visit each other's classes. When this was not possible due to the distance between teachers' schools or time constraints, the teachers were encouraged to film their classes and meet to discuss them. Third, after one or two observations, the group started collecting data to narrow down the problem. Many groups used questionnaires to get information from their students. Others analyzed the results of ordinary activities they gave to their students.

Fourth, the group analyzed the data collected and made plans to implement different actions in their classes. The implementation was not exactly the same for every teacher since they considered their students' needs, interest and age, the course program and time constraints.

The guidelines for the presentations are in the Appendix. 
Fifth, all teachers brought the results of their actions and they were assessed by everyone in the group. This led to new implementations, new observations and new assessment. This cycle encouraged teachers to see the new actions as part of the professional development they were engaged in.

\section{Results}

The results of this experiment can be understood according to three major aspects. The first one is related to the understanding of the goals and meanings of action research itself, the second one is about the process of carrying on collaborative action research and the third one is associated with the different levels of participants commitment to the research. In addition to these aspects, it is also important to discuss the positive outcomes of this experience, which led us to improve our approach to developing teachers' autonomy as it will be discussed below. In this article, we have decided to focus both on the difficulties that emerged during the year we first implemented the collaborative action research in the Continuing Education Program as well as on the positive outcomes of the experience, which made us believe that collaborative action research is a very important tool for professional development, as the final evaluation of the whole experience has revealed.

\subsection{Different processes: misconception of action research}

Although our experience predicted different ways of approaching the theoretical basis of action research, as well as the roles and importance of collaboration in order to have participants aware of the steps to be followed during the research process, some participants misunderstood what action research actually is and came out with results that differed from our initial expectations There was an alternative to present innovative activities developed in their classrooms; however, most participants chose to carry out the action research option. This way, although some groups considered their work as being the result of action research, the outcomes in fact, were the development of teaching plans and projects, the implementation of new techniques, the development of materials and the production of theoretical papers. In analyzing these results, it can be concluded that because of its bottom up nature, the participants' choice still led them to 
become more autonomous, as well as more motivated to develop action research in the future.

\subsection{Different levels of commitment}

Another challenge we had to face was related to the different levels of commitment to the Collaborative Action Research Project. Some participants would complete their tasks according to the project schedule, others would delay most of the required activities. Some group members would skip meetings or be late with their activities, others would schedule extra meetings. It was possible to infer that some of these problems could be explained by the inherent difficulties of the challenge of doing research for the first time. Participants continuously reported lack of confidence in the quality of what they had been doing. They found it difficult to formulate a research problem, define the objective of actions and narrow the focus of their analysis. Also, the presentation of the results meant another problem to be overcome, as the participants were not familiar with that academic practice and some of them did not have the language skills necessary for it. Moreover, since the presentations were supposed to include the results of their achievement, some participants still seemed to be unaware of the meanings of the research process they had just experienced. Based on this set of observations, the coordinators decided to employ a more directive approach to providing feedback for participants written papers and presentations in the second semester of the project. There was also the concern of reinforcing the theoretical and practical principles of actionresearch in all methodology classes.

The inexperience with the development of a research project is not the only issue that explains the different levels of participants' commitment. The collaborative aspect of the work was also a challenge for the teachers. Many participants did have a very heavy workload (some of them had a three shift working day), so that it became very difficult for them to find time to schedule extra meetings with other group members. It is important to draw attention to the fact that online meetings or communication was not an effective possibility as only a small number of participants had either access to a PC or the necessary skills to work with it. Certainly, though, we consider it extremely important to emphasize the fact that any teacher education strategy has to take into account teachers' working 
conditions as fundamental for the success of any approach undertaken to foster their autonomy (Jorge 2005).

At the end of the project, we realized that first year student-teachers were more motivated and committed to the research process than the second year students. This information can be explained by the teachers' working conditions. In the second year of EDUCONLE, it was harder for them to be out of schools to attend our course, and the school staff would not be very responsive to or supportive of the teachers' participation in our Continuing Education Program.

So far we have mentioned some of the challenges we had to face while carrying on a collaborative action research project with student-teachers. From this point on, we will highlight the successful outcomes of the experience based mainly on the results of the groups' performance as well as our reflection that lead us to implement changes in our Continuing Education Program in the following year.

\subsection{Successful outcomes and new actions}

One of the most prominent aspects we noticed is that the studentteachers, in spite of all new challenges to be faced, were quite motivated to organize their research and present their results. The most successful groups were able to determine the research topic and choose the suitable instruments to determine the research problem, such as questionnaires to assess students' desires and beliefs. These types of questionnaires have been used, from time to time, by different action research groups. The student-teachers, who at first believed their students were not interested in English, taking into consideration their lack of participation in class, surprisingly discovered that their students were eager to learn English. ${ }^{5}$ Such groups figured out, then, that students' little participation was due to other factors, for example, poor class planning, overemphasis on linguistic forms disconnected from meaning and use, few communicative activities in the classroom, confusing instructions for students to carry out activities.

\footnotetext{
5 Thanks to Phil Benson who pointed out to us that this change on teachers' beliefs about their students might be formulated as the following: "Perhaps this kind of enhanced awareness of one's students as people is a first step towards teacher autonomy."
} 
It was also possible for some of the groups to make a clear connection with the theory studied in the methodology classes. As mentioned above first year student-teachers seemed to be more willing to try alternatives in their professional life and some of them have spontaneously referred to collaborative action research as the door to envision new possibilities in their pedagogical practice and a chance to put into practice the theories they had been studying. In a study that aimed at detecting teachers' resignification of beliefs and professional changes, Arruda's (2008: 43) participant explicitly talked about collaborative action research as the dividing line in his first year in the continuing education program as his lesson plans started to include issues not yet explored in his practice:

Actually, I only started to change my way of teaching when the "action-research" project began in our course. Our group started to think and practice the theory with together with our experience and reality of each member with the support of our supervisor. From then on, I followed new perspectives when planning a class. However, this did not mean that I totally abandoned my old expository class, but, now, I can count on more flexibility to prepare my class.

Various topics were chosen by the groups to be worked on, and the problems posed were narrowed down or redefined during the course of the year. Some of the problems teachers wanted to solve in their classes were students' problems in a) writing, b) listening comprehension, c) reading, and d) doing grammar and translation exercises. One of the groups first determined that their students used the target language very little in the classroom. Upon group reflection they realized that they should investigate the implementation of listening comprehension activities in their classes, as students were not comfortable with this essential skill for oral production and neither were they with carrying out such activities. In their written report they wrote:

The need of doing an action research with beginner students of English was a consequence of five teachers' perception that the listening skill must be practiced since the beginning of students' contact with the target language so that they are acquainted with it and feel it as natural as possible. Besides, the action research participants found out that they also had great difficulties in working with this skill and wanted to get to know how to deal with this problem and solve it. (Fernandes et al. 2007:6)

This group had two participants implement the listening comprehension activities in their classes and the three other members were 
observers. They reported on all the steps the group planned from a questionnaire about students' difficulties to the observation of the class. The group presented both students positive and negative feelings about the activities as well as their opinions. One student said:

I feel more comfortable in listening to English and the teacher pronouncing English words. But it isn't every day that I listen to the teacher speaking English because I have just an English class a week. I like to listen to someone talking in English. (Fernandes et al. 2007: 25)

The student-teachers concluded that

the more listening activities the teachers propose to their students, the more the students are going to accept the target language in the classroom. The teachers believe that the positive results of this research are due to their preparation in advance for each activity proposed. (Fernandes et al. 2007:33)

Some of the groups presented role-plays, videos and also invited some of their actual students to join them during the presentations at UFMG. The general reaction was associated with a sense of achievement and the realization of what action research is about. The seminars made action research seem more "concrete" and "possible" to be done.

After a whole year focusing on the use of collaborative action research as a tool for promoting teacher's autonomy and reflection, we had several questions to be answered. Why did the first year students' outcome seem better than the second years'? Were second year participants suffering from the burnout syndrome? What should we know about the teachers before leading them into a process of self-awareness and research? To what extent were we successful? Was there real collaboration? Some of the questions had their answers presented above, and others are still to be answered. However, all the experience reported here has led us to introduce some changes in our own practice as teacher educators.

The first thing we decided to do was to consider the portfolios used as part of student-teachers' assessment as the initial instrument to analyze classroom practice. Although the participants had a previous experience in doing portfolios in the program, we decided to reinforce the ideas that the artifacts included in the portfolios could be a starting point to detect a problem in their classroom and even find solutions to previous practice. 
Second, we decided to approach collaboration in a more innovative way, creating a course on "Classroom Ethnography" which requires undergraduate students from our college to pair with EDUCONLE's students and develop an ethnographic project in school settings. This way, we have the expectation that in-service education and pre-service education can be integrated in order to have the newcomers and the more mature professionals help each other in finding new ways to autonomy.

\section{Conclusion}

This paper aimed at discussing autonomy in the light of a collaborative action research initiative with fifty English public school teachers engaged in a continuing education program. The complex implementation of such enterprise made us cautious about having action research as a mandatory module of the continued teacher program we coordinate. The results obtained ranged from groups that could not narrow down their topic even after two terms of orientation with regular meetings and suggestions from the group advisor to groups that were able to clearly define their classroom problem and look for alternative practices, which were evaluated throughout the year. The most successful groups did not stop at the good results they encountered in the first term and were able to establish more challenging goals for their learners, showing how their autonomy could be exercised with the help of this systematic inquiry which favoured reflection and focused on practice: collaborative action research. We believe the seed of critical reflection has been planted on the path of some teachers involved in our action research project as they saw that they themselves and their classrooms could be transformed through their involvement in collaborative dialogue. As Fernandes et al. (2007:33) wrote in the conclusion of their research report: The research teachers learned that reflection and collaborative work play a very important role in their pedagogical practice. They got to the conclusion that it is possible to conduct a research project and that their peers' help is very meaningful and encouraging.

Recebido em maio de 2008 Aprovado em dezembro de 2008 E-mail: heliana.mello@gmail.com dpdutra@terra.com.br mlsj54@hotmail.com 


\section{REFERENCES}

AllWright, D. 2003. Exploratory Practice: rethinking practitioner research in language teaching. Language Teaching Research 7, 2: 113-141.

ArRuda, C. F. B. 2008. O processo de ressignificação de crenças e mudança da prática pedagógica de um professor de inglês em formação continuada. Unpublished thesis. Programa de Pós-Graduação em Estudos Lingüísticos, Universidade Federal de Minas Gerais.

Barfield, A., Ashwell, T., Carroll, M., Collins, K., Cowie, N., Critchley, M., Head, E., Nix, M., Obermeier, A. \& M.C. Robertson. 2001. Exploring and defining teacher autonomy. Forthcoming. In: Developing Autonomy, Proceedings of the College and University Educators. Conference, Shizuoka, Japan. Tokyo: The Japan Association for Language Teaching.

Bartlett, L. 1990. Teacher development through reflective teaching. In: Richards, J.C. \& D. Nunan (eds.). Second language teacher education (pp. 202-214), Cambridge: Cambridge University Press.

Benson, P. 2001. Teaching and researching autonomy in language learning. London: Pearson Education.

Benson, P. \& D. Nunan (eds.). 2005. Learners' stories: Difference and diversity in language learning. Cambridge: Cambridge University Press.

Benson, P. \& S. Toogood (eds.). 2001. Learner autonomy 7: Challenges to research and practice. Dublin: Authentik.

Benson, P. \& P. Voller (eds.).1997. Autonomy and independence in language learning. London: Longman.

Bergen, P. 1990. Developing autonomous learning in the foreign language classroom. Bergen: Universitetet i Bergen Institutt for praktisk pedagogikk. In: Dam, L. 1995, Learner autonomy: From theory to practice (pp.1-2), Dublin: Authentik.

Dam, L. \& Little, D. 1999. Autonomy in foreign language learning: From classroom practice to generalizable theory. In Barfield, A.W., Betts, R., Cunningham, J., Dunn, N., Katsura, H., Kobayashi, K., Padden, N., Parry, N. \& M. Watanabe (eds.), On JALT98: Focus on the Classroom: Interpretations (pp.127-136), Tokyo: The Japan Association for Language Teaching.

Dutra, D. P.; Mello, H. 2004. Pesquisa-ação colaborativa e o desenvolvimento da competência lingüística. Paper presented at VII Congresso Brasileiro de Lingüística Aplicada. São Paulo: LAEL/PUC-SP. 
Dutra, D. P. 2005. Narrativas de professores como instrumento de reelaboração da conceptualização sobre competência lingüística. Paper presented at $15^{\circ}$ InPLA - Linguagem: Desafios e Posicionamentos. São Paulo: LAEL/PUC-SP.

Fernandes, C.; Ribeiro, J; Oliveira, M.; Pinto, R. \& Barbosa, R. 2007. Facing the challenges of using the target language in the English classes: An action research project on the listening skill. Unpublished research report. Universidade Federal de Minas Gerais.

Freeman, D. 1998. Doing teacher research. Rowley, Mass.: Newbury House. Jesus, A.; Mello, H.; Dutra, D. P. 2007 Reflective collaborative partnership enlightening new classroom practices. In H. Mcgarrell (ed.). Language Teacher Research in the Americas. Alexandria, VA: TESOL. Pp. 95-112.

Johnson, K. E. 2006. The sociocultural turn and its challenges for second language teacher education. TESOL Quarterly, 40.1: 235-257. 56-69.

Jorge, M. L. S. 2005. O diálogo colaborativo na formação de professores de inglês. Unpublished dissertation. Programa de Pós-Graduação em Estudos Lingüísticos, Universidade Federal de Minas Gerais.

LitTLe, D. 1991. Learner autonomy 1: Definitions, issues and problems. Dublin: Authentik.

. 1995. Learning as dialogue: The dependence of learner autonomy on teacher autonomy. System 23.2: 175- 182.

LittLe, D. 7-9 September, 2000. We're all in it together: Exploring the interdependence of teacher and learner autonomy. Paper presented at Autonomy 2000. University of Helsinki Language Centre.

LitTlewood, W. 1999. Defining and developing autonomy in East Asian contexts. Applied Linguistics 20 (1): 71-94.

Mcgrath, I. 2000. Teacher autonomy. In: Sinclair, B., Mcgrath, I. \& T. Lamb (eds.). Learner autonomy, teacher autonomy. London: Longman.

Shor, I. \& Freire, P. 1987. A pedagogy for liberation. New York: Bergin \& Garvey.

Smyth, J. 1989. Developing and sustaining critical reflection in teacher education. Journal of Teacher Education 40 (2): 2-9.

Wellington, B. \& Austin, P. 1996. Orientations to reflective practice. Educational Research 38 (3): 307-316. 


\section{Appendix}

Seminar Guidelines - Answer the questions below as you prepare the seminar

1. Research topic

a) Did the research topic change during the research process?

b) What were the steps followed to focus on the research topic?

2. Data collection
a) How were the observations undertaken?
b) How many classes did your group observe?
c) What kind of punctual observations did you make?
d) How did the journal writing help you understand your and your classmates' practice?
e) Did your group use any other instrument for data collection, such as questionnaires? How did it help you focus on the research topic?

3. Implementing changes
a) What are your plans to solve your group's problem?
b) How did you get to the plan you just proposed?
c) What are the results you expect to get from the implementation of the plan?

4. Theory and practice connection
a) Which theories helped you focus on the research topic?
b) Which theories helped you propose solutions? 